\title{
Development and Evaluation of Shiitake Mushroom (Lentinus edodus) Instant Soup Mixes
}

\author{
Jyoti Singh, Sangeeta C. Sindhu* and Varsha Kumari \\ Department of Foods and Nutrition, COHS, CCSHAU, Hisar 125004, Haryana, India \\ *Corresponding author
}

\section{A B S T R A C T}

Keywords

Nutrient

composition,

Sensory evaluation,

Shiitake mushroom,

Storage studies,

Total bacterial

count, Value

addition.

Article Info

Accepted:

12 April 2017

Available Online:

10 May 2017
The instant soup mixes were prepared from treated and untreated mushroom pieces. Shiitake (Lentinus Edodus) mushroom was solar dried following citric acid treatment. The untreated mushroom was sun dried. The developed instant soup mixes were evaluated for sensory and nutritional attributes and were stored for one month at room temperature. The stored soup mixes were evaluated for sensory qualities and total bacterial count. The developed soup mixes were acceptable to judges and had a good nutritional profile with a protein content $13.96 \pm 0.14$ to $14.52 \pm 7.21 \mathrm{~g} / 100 \mathrm{~g}$, total carbohydrate $76.27 \pm 2.35$ to $76.28 \pm 2.29 \mathrm{~g} / 100 \mathrm{~g}$, total fibre $16.61 \pm 0.65$ to $16.81 \pm 2.84 \mathrm{~g} / 100 \mathrm{~g}$, soluble fibre $5.45 \pm 0.16$ to $5.88 \pm 0.10$ $\mathrm{g} / 100 \mathrm{~g}$, phosphorus content $842.27 \pm 1.76$ to $854.00 \pm 1.73$ and iron content $7.60 \pm 0.31$ to $8.62 \pm 0.47 \mathrm{mg} / 100 \mathrm{~g}$. The total bacterial count of curries varied from 0 to $4 \times 10^{2} \mathrm{cfu} / \mathrm{g}$ of product during 0 to 30 th day of storage.

\section{Introduction}

Lentinus edodes, the Shiitake mushroom, is one of the most widely cultivated mushrooms worldwide. The interest in shiitake cultivation is increasing because of its high nutritional value and medicinal properties, which have been acknowledged by oriental cultures, especially in China and Japan (Hassegawa et al., 2005; Bisen et al., 2010). Interest in numerous biologically active compounds produced by this mushroom is also increasing.

Shiitake mushrooms have been attributed with many medicinal properties by both eastern and western medicine. They range from reducing cholesterol, lowering blood pressure, strengthening the immune system against diseases including viral ones, fighting tumors, and improving liver function (Finimundy et al., 2014). Many of the shiitake health benefits come from chemical compounds these mushrooms produce, these include: lentinan, eritadenine, L-ergothioneine. Lentinan has shown some effect on bowel cancer, liver cancer, stomach cancer, ovarian cancer, lung cancer and AIDS (Okamoto et al., 2004; Enman et al., 2007).

Mushrooms are rapidly perishable commodities, and they start deteriorating immediately within a day after harvest. In view of their highly perishable nature, the fresh mushrooms have to be processed to 
extend their shelf life for off-season use. Drying is a comparatively cheap method and dried mushrooms, packed in airtight containers can have a shelf life of above one year. Pretreatments of mushrooms before drying in one form or other viz, washing in water, potassium metabisulphite (KMS), sugar, salt either alone or in combination are known to help in checking enzymatic browning, stabilizing colour, enhancing flavour retention and maintaining textural (Izli and Isik, 2014; Jiang et al., 2015).

Present article summarizes the development of instant soup mixes from treated and untreated dehydrated Shiitake mushroom and its nutritional, sensory and microbial attributes.

\section{Materials and Methods}

All the ingredients were procured from open market in a single lot, cleaned and stored in air tight food grade container. Mushrooms were washed in running tap water and sliced before treatment. Mushrooms were divided into two lots. One lot was given pre drying treatment by dipping for $15 \mathrm{~min}$ in a solution containing $5 \mathrm{~g} / \mathrm{L}$ Citric acid. The treated mushrooms were solar dried after that. Second lot was not given any pre drying treatment and was dried under open sun.

\section{Development of soup mixes}

The ingredient were carefully and accurately weighted (Mushroom (pieces) 20 g, Skim milk powder $40 \mathrm{~g}$, Onion (Blanched and oven dried) $10 \mathrm{~g}$, Salt $5 \mathrm{~g}$, Black pepper powder $3 \mathrm{~g}$, Corn flour $5 \mathrm{~g}$, Refined oil $10 \mathrm{~g}$, Ajinomoto $1 \mathrm{~g})$. All ingredients were mixed together and filled in the retort pouch. It was sterilized at $121^{\circ} \mathrm{C}$ for $43 \mathrm{~min}$ and cooled rapidly. Soup mix I contained untreated mushrooms while Soup mix II contained treated mushrooms. For preparation of soup, $100 \mathrm{ml}$ of water was added to $10 \mathrm{~g}$ of soup mix and boiled while stirring for $5 \mathrm{~min}$.

\section{Sensory, nutritional and shelf life evaluation}

Sensory evaluation of developed products was carried out according to 9 points hedonic scale (Ranganna, 1986) by a panel of ten semi trained judges. The developed soup mixes were analysed for Proximate composition (AOAC, 2000), dietary fibre constituents (Furda, 1981), total carbohydrate (by addition method), total soluble sugars (Yemm and Willis, 1954), reducing sugars (Somogyi, 1945), non -reducing sugars (by difference) and starch (Clegg, 1956). In vitro protein digestibility was also determined (Mertz et al. 1983). Total iron, zinc, calcium and phosphorus in acid digested samples were determined by the atomic absorption spectrophotometer (Lindsey and Norwell, 1969). Mineral $\mathrm{HCl}$ extractability (Peterson, et al., 1943) and polyphenols (Singh and Jambunathan, 1981) were also studied. Ready to use soup mixes were stored at room temperature $\left(30 \pm 2{ }^{\circ} \mathrm{C}\right)$ in for one month and subjected to sensory analysis at intervals of 15 and 30 days of storage. The fat acidity was determined by the standard method of analysis (AOAC, 2000). The stored soup mixes were also studied for microbial growth (using PCA media) at storage intervals of 15 and 30 days.

\section{Statistical analysis}

Suitable standard statistical methods were used for analysis of data (Sheoran and Pannu, 1999).

\section{Results and Discussion}

Moisture content was 83.69 and 84.04 per cent in soup I and soup II. Crude protein and crude fat in soup I were 14.52 and 5.80 per 
cent. Total ash was 2.38 and 2.37 per cent in soup I and II. Crude fibre was 1.02 per cent in soup I and 1.62 per cent in soup II. Crude protein content of soup I was significantly $(\mathrm{P} \leq 0.05)$ higher than soup II (Table 1$)$. Total carbohydrates in soup I and soup II were 76.28 and 76.27 per cent respectively. Total soluble sugar was 20.47 per cent in soup I and 20.42 per cent in soup II. Reducing and non reducing sugars were 1.51 and 18.95 (soup I), 1.67 and 18.74 (soup II), respectively. Starch content of soup I (29.92\%) was significantly $(\mathrm{P} \leq 0.05)$ higher than of soup II $(27.63$ $\%)$.Total fibre, soluble and insoluble fibre in soup I were $16.81,5.45$ and $11.35 \mathrm{~g} / 100 \mathrm{~g}$ and these were to $16.61,5.88$ and $10.01 \mathrm{~g} / 100 \mathrm{~g}$ in soup II. The insoluble fibre of soup II was significantly $(\mathrm{P} \leq 0.05)$ lower than soup $\mathrm{I}$. Polyphenol content in soup I was 169.81 $\mathrm{mg} / 100 \mathrm{~g}$ which was significantly $(\mathrm{P} \leq 0.05)$ lower in soup II i.e. $162.70 \mathrm{mg} / 100 \mathrm{~g}$. In vitro protein digestibility of soup I was 60.97 per cent and that was significantly $(\mathrm{P} \leq 0.05)$ higher in soup II (75.27\%) (Table 1). Total iron, zinc, phosphorus and calcium were 7.60, $8.14,842.27$ and 38.81 respectively in soup I. These were $8.62,8.26,854.00$ and 39.75 $\mathrm{mg} / 100 \mathrm{~g}$ in soup II with no significant $(\mathrm{P} \leq 0.05)$ differences observed among the two soups. $\mathrm{HCl}$ extractability of iron, zinc, phosphorus and calcium were 63.39, 92.95, 47.42 and 58.97 per cent respectively in soup I. $\mathrm{HCl}$ extractability of all the minerals were significantly $(\mathrm{P} \leq 0.05)$ higher in soup II (70.60, 96.39, 57.75 and $67.57 \%$ for iron, zinc, phosphorus and calcium respectively) (Table 2).

Table.1 Nutritive value of ripe mango per $100 \mathrm{~g}$

\begin{tabular}{|c|c|c|c|}
\hline \multirow[t]{2}{*}{ Component } & \multicolumn{3}{|l|}{ Content } \\
\hline & Soup I & Soup II & 't' value \\
\hline \multicolumn{4}{|l|}{ Proximate composition (\%) } \\
\hline Moisture & $83.69 \pm 0.40$ & $84.04 \pm 0.74$ & 0.71 \\
\hline Crude protein & $14.52 \pm 7.21$ & $13.96 \pm 0.14$ & $3.49 *$ \\
\hline Crude Fat & $5.80 \pm 0.24$ & $5.78 \pm 0.14$ & 3.38 \\
\hline Total Ash & $2.38 \pm 0.96$ & $2.37 \pm 0.27$ & 3.50 \\
\hline Crude Fibre & $1.02 \pm 2.19$ & $1.62 \pm 0.17$ & 1.65 \\
\hline \multicolumn{4}{|l|}{ Carbohydrate composition (\%) } \\
\hline Total Carbohydrate & $76.28 \pm 2.29$ & $76.27 \pm 2.35$ & 0.63 \\
\hline Total Soluble sugars & $20.47 \pm 0.30$ & $20.42 \pm 0.30$ & 0.12 \\
\hline Reducing sugar & $1.51 \pm 0.21$ & $1.67 \pm 0.22$ & 0.51 \\
\hline Non-Reducing Sugars & $18.95 \pm 0.11$ & $18.74 \pm 0.13$ & 1.21 \\
\hline Starch & $29.92 \pm 1.01$ & $27.63 \pm 0.57$ & $3.08 *$ \\
\hline \multicolumn{4}{|l|}{ Dietary fibre constituents(g/100g) } \\
\hline Total fibre & $16.81 \pm 2.84$ & $16.61 \pm 0.65$ & 0.29 \\
\hline Soluble fibre & $5.45 \pm 0.16$ & $5.88 \pm 0.10$ & 2.14 \\
\hline Insoluble fibre & $11.35 \pm 0.18$ & $10.01 \pm 5.77$ & $6.97 *$ \\
\hline \multicolumn{4}{|c|}{ Antinutritional factor and In vitro protein digestibility } \\
\hline Polyphenol(mg/100g) & $169.81 \pm 2.12$ & $162.70 \pm 0.92$ & $3.06^{*}$ \\
\hline In vitro protein digestibility (\%) & $60.97 \pm 2.21$ & $75.27 \pm 1.96$ & $8.37 *$ \\
\hline
\end{tabular}


Table.2 Mineral composition and their $\mathrm{HCl}$ extractability in Shiitake mushroom Instant Soup mixes

\begin{tabular}{|l|l|l|l|}
\hline \multirow{2}{*}{ Component } & Content & Soup II & 't' value \\
\cline { 2 - 4 } & Soup I & \multicolumn{2}{|l|}{} \\
\hline Mineral content (mg/100g) & $7.60 \pm 0.31$ & $8.62 \pm 0.47$ & 1.78 \\
\hline Iron & $8.14 \pm 0.14$ & $8.26 \pm 0.08$ & 0.50 \\
\hline Zinc & $842.27 \pm 1.76$ & $854.00 \pm 1.73$ & 15.96 \\
\hline Phosphorus & $38.81 \pm 0.36$ & $39.75 \pm 0.24$ & 2.13 \\
\hline Calcium & \multicolumn{3}{|l}{} \\
\hline HCl extractability (\%) & $63.39 \pm 1.75$ & $70.60 \pm 0.36$ & $4.02^{*}$ \\
\hline Iron & $92.95 \pm 0.80$ & $96.39 \pm 1.76$ & $0.38^{*}$ \\
\hline Zinc & $47.42 \pm 0.01$ & $57.75 \pm 0.68$ & $0.83^{*}$ \\
\hline Phosphorus & $58.97 \pm 3.75$ & $67.57 \pm 0.93$ & $2.22^{*}$ \\
\hline Calcium
\end{tabular}

Values are mean \pm SE of three independent determinations

Soup I = Untreated mushroom, Soup II = Treated mushroom

' $\mathrm{t}$ ' value with *denotes significant $(\mathrm{p} \leq 0.05)$ difference in the given row

Table.3 Sensory characteristics of Shiitake mushroom instant soup mixes after storage

\begin{tabular}{|l|c|c|c|c|}
\hline \multirow{2}{*}{ Treatment } & 0 & 15 & 30 & CD(P $\leq \mathbf{0 . 0 5})$ \\
\cline { 2 - 5 } & \multicolumn{5}{|c|}{ Colour } \\
\hline Soup I & $8.00 \pm 0.14$ & $7.92 \pm 0.10$ & $7.72 \pm 0.11$ & NS \\
\hline Soup II & $8.25 \pm 0.17$ & $8.15 \pm 0.15$ & $8.15 \pm 0.13$ & NS \\
\hline \multicolumn{5}{|c|}{ Appearance } \\
\hline Soup I & $8.10 \pm 0.18$ & $7.80 \pm 0.15$ & $7.85 \pm 0.13$ & NS \\
\hline Soup II & $8.25 \pm 0.17$ & $8.15 \pm 0.13$ & $8.15 \pm 0.16$ & NS \\
\hline \multicolumn{5}{|c|}{ Aroma } \\
\hline Soup I & $7.95 \pm 0.21$ & $7.80 \pm 0.15$ & $7.80 \pm 0.50$ & NS \\
\hline Soup II & $7.95 \pm 0.20$ & $7.75 \pm 0.12$ & $7.75 \pm 0.21$ & NS \\
\hline \multicolumn{5}{|c|}{ Texture } \\
\hline Soup I & $7.90 \pm 0.28$ & $8.10 \pm 0.12$ & $8.12 \pm 0.11$ & NS \\
\hline Soup II & $8.25 \pm 0.20$ & $8.15 \pm 0.11$ & $8.20 \pm 0.21$ & NS \\
\hline \multicolumn{5}{|c|}{ Taste } \\
\hline Soup I & $7.60 \pm 0.20$ & $7.60 \pm 0.17$ & $7.52 \pm 0.15$ & NS \\
\hline Soup II & $8.00 \pm 0.21$ & $7.85 \pm 0.13$ & $7.80 \pm 0.10$ & NS \\
\hline \multicolumn{5}{|c|}{ Overall Acceptability } \\
\hline Soup I & $7.91 \pm 0.08$ & $7.84 \pm 0.24$ & $7.70 \pm 0.26$ & NS \\
\hline Soup II & $8.14 \pm 0.06$ & $7.82 \pm 0.13$ & $7.90 \pm 0.17$ & NS \\
\hline
\end{tabular}

Values are mean \pm SE of ten independent determinations

Soup I = Untreated mushroom, Soup II = Treated mushroom 
Table.4 Effect of storage period on fat acidity (mg KOH/100gm) of Shiitake mushroom soup mixes (on dry weight basis)

\begin{tabular}{|c|c|c|c|c|}
\hline \multirow{2}{*}{ Treatment } & \multicolumn{4}{|c|}{ Storage (days) } \\
\cline { 2 - 5 } & $\mathbf{0}$ & $\mathbf{1 5}$ & $\mathbf{3 0}$ & $\mathbf{C D}(\mathbf{P} \leq \mathbf{0 . 0 5})$ \\
\hline Soup I & $2.39 \pm 0.38$ & $2.64 \pm 0.28$ & $2.97 \pm 0.29$ & 0.66 \\
\hline Soup II & $2.36 \pm 0.50$ & $2.42 \pm 0.47$ & $2.45 \pm 0.45$ & 0.97 \\
\hline
\end{tabular}

Values are mean \pm SE of three independent determinations

Soup I = Untreated mushroom, Soup II = Treated mushroom

Table.5 Total bacterial count (cfu/g) of Shiitake instant soup mixes at different storage periods

\begin{tabular}{|l|l|l|l|}
\hline \multirow{3}{*}{ Treatment } & \multicolumn{2}{|l|}{ Storage period (days) } \\
\cline { 2 - 4 } & Total bacterial count (cfu/g) & $\mathbf{3 0}$ \\
\cline { 2 - 4 } & $\mathbf{0}$ & $\mathbf{1 5}$ & $4 \times 10^{2}$ \\
\hline Soup I & 0 & $1 \times 10^{1}$ & $2 \times 10^{2}$ \\
\hline Soup II & 0 & 0 & \\
\hline
\end{tabular}

Soup I = Untreated mushroom; Soup II = Treated mushroom

Plate.1 Soup I = Untreated mushroom soup; Soup II = Treated mushroom soup

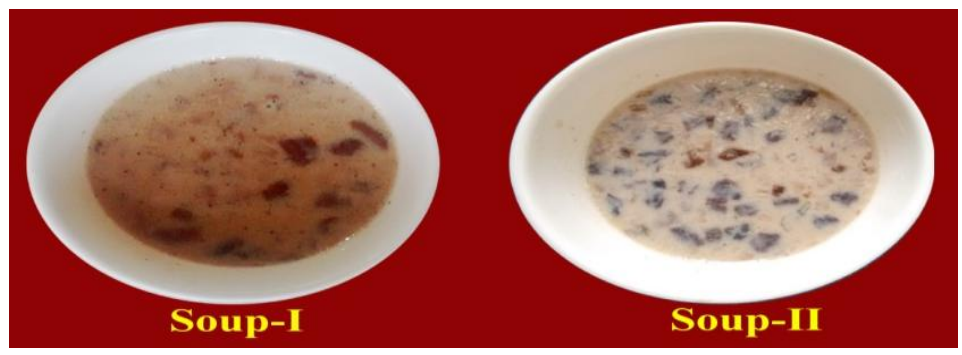

Both soup mixes had acceptable mean scores on 0 day with no significant $(\mathrm{P} \leq 0.05)$ difference up to $30^{\text {th }}$ day of storage (Table 3 ). The fat acidity of soup mixes exhibited nonsignificant $(\mathrm{P} \leq 0.05)$ changes during storage period (Table 4). The total bacterial count of soup I varied from 0 to $4 \times 10^{2}(\mathrm{cfu} / \mathrm{g})$ of instant soup mix during 30 days of storage. The total bacterial count of Type I soup and Type II ranged from 0 to $4 \times 10^{2}$ and 0 to $2 \times 10^{2} \mathrm{cfu} / \mathrm{g}$ of soup, respectively. These were within the acceptable range upto $30^{\text {th }}$ days of storage (Table 5).

The Shiitake, is highly prized in Asia for its nutritional qualities such as high protein, dietary fibers and important mineral contents, vitamins B1, B2, B3 and B12 (in trace amounts), vitamin $\mathrm{C}$, ergosterol and the provitamin D2 (Regula and Siwulski,2007; Ko et al.,2008). Shiitake is rich in several anti-oxidants (selenium, uric acid, vitamin A, E, C) as well as vitamin D (Kitzberger et al., 2007; Zembron et al., 2013). Similar work on product development from mushrooms, their evaluation and shelf life has been reported by various other authors (Bora and Kawatra, 2014 Singh and Sindhu, 2016; Singh et al., 2016a; Singh et al., 2016b).

In conclusion the developed products were organoleptically acceptable. The developed 
products could be stored successfully upto 30 days. It can be concluded that the Shiitake mushroom has a potential for use in food processing industry.

\section{References}

AOAC. 2000. Official Methods of Analysis, 17th edition. Association of the Official analytical Chemists, Washington D.C, USA.

Bisen, P.S., Baghel, R.K., Sanodiya, B.S., Thakur, G.S. and Prasad, G.B.K.S. 2010. Lentinus edodes: a macrofungus with pharmacological activities. Curr. Med. Chem., 17(22): 2419-2430.

Bora, P. and Kawatra, A. 2014. Study on nutritional evaluation and composition of oyster mushrooms (Pleurotus florida). Food Sci. Res. J., 1(5): 56-58.

Clegg, K.M. 1956. The application of anthrone reagent to the estimation of starch in cereals. J. Sci. Food Chem. Agric., 7: 40-44

Enman, J., Rova, U. and Berglund, K.A. 2007. Quantification of the bioactive compound eritadenine in selected strains of shiitake mushroom (Lentinus edodes). J. Agric. Food Chem., 55(4): 1177-1180 doi: 10.1021/jf062559

Finimundy, T.C., Dillon, A.J.P., Henriques, J.A.P. and Ely, M.R. 2014. A review on general nutritional compounds and pharmacological properties of the Lentinula edodes mushroom. Food Nutr. $\quad$ Sci., 5: 1095-1105. doi:10.4236/fns.2014.512119

Furda, I. 1981. Simultaneous analysis of soluble and insoluble dietary fibre. In W.P.T. James, and O. Theander (Eds.). The Analysis of Dietary Fibre in Food. Marcel Dekker, New York, pp. 163172.

Hassegawa, R.H., Kasuya, M.C.M. and Vanetti, M.C.D. 2005. Growth and antibacterial activity of Lentinula edodes in liquid media supplemented with agricultural wastes. Electron. J. Biotech., 8(2): 212-215.

Izli, N. and Isik, E. 2014. Effect of different drying methods on drying characteristics, colour and microstructure properties of mushroom. J. Food \& Nutrition Res., 53(2): 105116.

Jiang, N., Liu, C., Li, D. and Zhou, Y. 2015. Effect of blanching on the dielectric properties and microwave vacuum drying behavior of Agaricus bisporus slices. Innovative Food Sci. Emerg. Technol., 30: 89-97.

Kitzberger, C.S.G., Smânia, A., Pedrosa, R.C. and Ferreira, S.R.S. 2007. Antioxidant and antimicrobial activities of shiitake (Lentinula edodes) extracts obtained by organic solvents and supercritical fluids. J. Food Engg., 80(2): 631-638.

Ko, J.A., Lee, B.H., Lee, J.S. and Park, H.J. 2008. Effect of UV-B exposure on the concentration of vitamin D2 in sliced shiitake mushroom (Lentinus edodes) and white button mushroom (Agaricus bisporus). J. Agric. Food Chem., 56(10): 3671-3674. doi: 10.1021/jf073398s

Lindsey, W.L. and Norwell, M.A. 1969. A new DPTA-TEA soil test for zinc and iron. Agron. Abst. , 61: 84.

Mertz, E.T., Kirleis, A.W. and Sxtell, J.D. 1983. In vitro digestibility of protein in major food cereals. Fed. Proc., 32(5): 6026

Okamoto, T., Kodoi, R., Nonaka, Y., Fukuda, I., Hashimoto, T., Kanazawa, K. and Ashida, H. 2004. Lentinan from shiitake mushroom (Lentinus edodes) suppresses expression of cytochrome P450 1A subfamily in the mouse liver. Biofactors, 21(1-4): 407-409. PMID: 15630237

Peterson, W.H. 1943. Elements of Food Biochemistry. Prentice Hall, Inc. New 
York, $73 \mathrm{p}$.

Ranganna, S. 1986. Manual of analysis of fruits \& vegetable products. Tata Mc Graw Hills Publishing Company LTD., New Delhi.

Reguła, J. and Siwulski, M. 2007. Dried shiitake (Lentinulla edodes) and oyster (Pleurotus ostreatus) mushrooms as a good source of nutrient. Acta Sci. Pol. Technol. Aliment, 6(4): 135-142.

Sheoran, O.P. and Pannu, R.S. 1999. Statistical software package for agricultural research workers In Recent advances in information theory, Statistics and Computer application. Eds. Hooda DS and Hasija RC., pp. 139-143.

Singh, J. and Sindhu, S.C. 2016. Nutritional, sensory and microbial attributes of ready to use Shiitake (lentinus edodus) mushroom curry. Int. J. Appl. Biol. Pharmaceutical Technol., 7(2): 140146.

Singh, J., Sindhu, S. C. and Sindhu, A. 2016a. Development and evaluation of value added pickle from dehydrated shiitake (lentinus edodes) Mushroom. Int. J.
Food Sci. Nutri., 1(1): 24-26. file:///C:/Users/hp/Downloads/1-114\%20(1).pdf

Singh, J., Sindhu, S.C., Sindhu, A. and Yadav A. 2016b. Development and evaluation of value added biscuits from dehydrated Shiitake (lentinus edodes) mushroom. Int. J. Curr. Res., 8(3): 155-159.

Singh, U. and Jambunathanan, R. 1981. Studies on desi and kabuli chickpea cultivars, levels of protease inhibitors, polyphenolic compounds and in vitro protein digestibility. J. Fd. Sci., 46: 1364-1367.

Somogyi, M. 1945. A new reagent for the determination of sugar. J. Biol. Chem., 160: 60-61.

Yemm, E.W. and Willis, A.J. 1954. The estimation of carbohydrates in plant extracts by anthrone. Biochem. J., 57: 508-514

Zembron, A., Gajewski, M., Naczk, M. and Siatkowski, I. 2013. Effect of shiitake (Lentinus edodes) extract on antioxidant and inflammatory response to prolonged eccentric exercise. J. Physiol. Pharmacol., 64(2): 249-254.

\section{How to cite this article:}

Jyoti Singh, Sangeeta C. Sindhu and Varsha Kumari. 2017. Development and Evaluation of Shiitake Mushroom (Lentinus edodus) Instant Soup Mixes. Int.J.Curr.Microbiol.App.Sci. 6(5): 1232-1238. doi: https://doi.org/10.20546/ijcmas.2017.605.133 